\author{
Agnieszka Wójcik-Mazur \\ Czestochowa University of Technology \\ e-mail: agnieszka.wojcik-mazur@wz.pcz.pl \\ ORCID 0000-0002-9275-5624
}

\title{
IDENTIFICATION OF THE DEPENDENCES BETWEEN LIQUIDITY RISK AND INTERNAL DETERMINANTS IN POLISH BANKS
}

IDENTYFIKACJA RELACJI POMIEDZY RYZYKIEM
PLYNNOŚCI A DETERMINANTAMI WEWNETRZNYMI
W POLSKICH BANKACH

DOI: $10.15611 / \mathrm{pn} .2019 .2 .12$

JEL Classification: G21, G32, M21

\begin{abstract}
Summary: This article assesses the correlation between the level of liquidity risk of banks operating in the Polish banking system and a group of internal determinants (including credit risk, measure of profitability and the value of capital ratio). The estimation of correlation coefficients was performed in a group of two types of banks representing the Polish banking sector i.e. commercial and cooperative banks. The study showed a correlation (statistically significant) between the level of liquidity and the internal determinants in the two groups of banks. Nevertheless, the existence of different directions of correlation between liquidity risk and the level of capital ratio in these two groups of Polish banks has been demonstrated. A strong positive relation between the level of liquidity and capital ratio has been diagnosed in the cooperative banking sector, which may be interpreted as an orientation of these banks to increase financial security, regardless of the phase of the economic cycle, which results from both the necessity to implement CRD regulation and the increase in the lending capability of cooperative banks.
\end{abstract}

Keywords: bank, liquidity risk, determinants of liquidity risk.

Streszczenie: W artykule dokonano oceny zależności pomiędzy ryzykiem płynności banków a wyselekcjonowaną grupą determinant wewnętrznych (obejmujących: poziom ryzyka kredytowego, udziału kapitału własnego w pasywach ogółem oraz rentowności). Badanie zależności obejmowało szacowanie współczynnika korelacji w dwóch grupach banków polskiego sektora, tj. spółdzielczych oraz komercyjnych. Przeprowadzone badania potwierdziły istnienie korelacji (statystycznie istotnej) pomiędzy poziomem płynności finansowej a determinantami wewnętrznymi dla banków zarówno komercyjnych, jak i spółdzielczych. Niemniej jednak wykazano istnienie różnych kierunków korelacji pomiędzy ryzykiem płynności a poziomem kapitału własnego. W sektorze banków spółdzielczych zdiagnozowano bowiem istnienie silnej dodatniej zależności pomiędzy poziomem płynności 
a udziałem kapitałów własnych w aktywach ogółem. Zależność ta może oznaczać ukierunkowanie banków spółdzielczych na zwiększenie bezpieczeństwa finansowego (niezależnie od cyklu koniunkturalnego) i jednocześnie wynikać z konieczności implementowania nowych regulacji CRD, jak również z chęci zwiększenia możliwości kredytowych tego sektora.

Słowa kluczowe: bank, ryzyko płynności, determinanty ryzyka płynności.

\section{Introduction}

The outbreak of the crisis and its negative consequences for the financial system and the real economy led to increased interest in the issue of liquidity risk in banking systems which has become a much more explored research area. The crisis has highlighted problems related to the management of banking liquidity risk [Jajuga 2009] from the level of a single financial institution on a global scale. and in particular concerning quantification issues. This is particularly due to the fact that liquidity risk is determined by a number of factors of both an internal nature resulting from the classical formula of the functions of financial intermediation, and macroeconomic impact, especially market liquidity. The problem of identifying the determinants of bank liquidity risk was not the subject of wide scientific discourse until the outbreak of the crisis. The consequences of the crisis focused the research on the problem of liquidity risk in the context of indicating the relationship between liquidity risk and the group of external determinants (GDP, inflation and the ratio of deposits to loans) and internal determinants i.e. credit risk level or profitability generated. Nevertheless, the results of the research are not homogeneous, particularly in relation to dependences between liquidity risk and the profitability level of bank-ROA, ROE [Wójcik-Mazur, Szajt 2015]. Empirical studies identifying the determinants of liquidity risk of Polish commercial banks were carried out by Vodova [Vodova 2013], however, it was focused on commercial banks. Therefore, this article is an attempt to describe relationship between the group of internal determinants and liquidity risk of both commercial and cooperative banks operating in the Polish banking system. The characteristics of cooperative banks, and their local nature may result in the different characteristics of these banks' liquidity policy. This paper evaluates the existence of the dependences between liquidity risk and credit risk level, profitability and the scope of capital ratio (calculated as the share of equity in total assets). Pearson correlation coefficients were used to diagnose those dependences, and they were estimated for the group of commercial and cooperative banks. Based on literature studies, the following hypotheses were formulated:

1. There is a positive linear correlation between liquidity risk and the level of profitability of banks, regardless of the type of bank. 
2. The level of credit risk is negatively correlated with liquidity risk, irrespective of the group of banks.

3. The level of capital ratio is negatively correlated with the risk of bank liquidity, irrespective of the type of the analyzed bank.

\section{Methods of measuring the liquidity risk of commercial banks in light of empirical research}

According to the Basel Committee, "liquidity is the ability of a bank to fund increases in assets and meet obligations as they come due, without incurring unacceptable losses" (the Basel Committee). It should be noted that liquidity risk is determined by both external and internal factors resulting from the type and nature of the activities of the financial institution. Hence it is widely emphasized in the literature that the liquidity risk in the activities of commercial banks includes two essential components - funding risk and market risk [Brunnermeier, Pedersen 2009; Nikolaou 2009; Vento, La Ganga 2009]. The specific nature of liquidity risk causes some problems with the appointment of metrics analysis. This applies not only to empirical studies but also creates difficulties related to the implementation of global standards governing mandatory safety thresholds to maintain liquidity reserves. It was only in response to the consequences of the last crisis that the Basel Committee introduced the necessity of estimating the liquidity measures in the short and long-term perspective including respectively: Liquidity Coverage Ratio (LCR) and Net Stable Funding Ratio (NSFR) [Basel III 2013; Basel III 2014; Dziwok 2015; Zaleska 2016].

According to the Basel Committee, "the objective of the LCR is to promote the short-term resilience of the liquidity risk profile of banks". The LCR should ensure that banks have an adequate amount of unencumbered high-quality liquid assets (HQLA). These assets can be converted easily and immediately in private markets into cash to meet their liquidity needs for a 30 calendar day liquidity stress scenario [Basel III 2013].

The NSFR means that the amount of "available stable funding" should be equal to at least the amount of stable funding required. "Available stable funding" is the proper amount of capital and liabilities expected over one year. The amount of stable funding required consists of various assets held by that institution and those of its off-balance sheet exposures. Their value and level is estimated by taking into account the factor of ASF, reflecting the funding stability level [Wójcik-Mazur 2012; Basel III 2014]. The effect of the above measures on the banking sector operation in Poland was analyzed e.g. by Marcinkowska et al. [2014], Dziwok [2015] and Niedziółka [2014].

In estimating the level of liquidity of each banking institution, three main methods for measurement taking into account the stock approaches, cash-flow and hybrid approaches can be used [Vento, La Ganga 2009]. 
Empirical studies related to identifying the determinants of liquidity risk and the determinants estimating the level of efficiency are based on a stock approach. The quantitative measurements of bank liquidity risk are used most often. They include: balance sheet ratios, net cash capital position, maturity mismatches and funding ratios. The problem of calculating these measurements depends on cash flow timing and its level of uncertainty. For that reason, in the spatio-temporal analysis declared cash flows are treated as certain. Implied measures of balance sheet assets include accounts with varying degrees of liquidity to total assets or selected sources of financing including deposits. Such possible ratios are presented in Table 1.

Table 1. Methods of bank's financial liquidity analysis

\begin{tabular}{|c|c|}
\hline $\begin{array}{l}\text { Balance sheet analysis } \\
\text { Assessment of asset liquidity } \\
\text { level }\end{array}$ & $\begin{array}{l}\text { Liquid assets / total assets; } \\
\text { High liquid assets / total assets; } \\
\text { Loans / total assets; } \\
\text { Very high liquid assets / total assets; } \\
\text { Deposits in financial sector / total assets; } \\
\text { Deposits in financial sector / liquid assets. }\end{array}$ \\
\hline $\begin{array}{l}\text { Balance sheet analysis } \\
\text { Assessment of liability } \\
\text { stability level }\end{array}$ & $\begin{array}{l}\text { Non-financial sector deposits / total liabilities; } \\
\text { Large deposits / total liabilities; } \\
\text { Overnight deposits / total liabilities; } \\
\text { Fixed-term deposits / total liabilities; } \\
\text { Debt instruments / total liabilities. }\end{array}$ \\
\hline $\begin{array}{l}\text { Balance sheet analysis } \\
\text { Financing (balance sheet) gap } \\
\text { and its derivatives }\end{array}$ & $\begin{array}{l}\text { Loans for non-financial sector } \\
\text { - non-financial sector deposits; } \\
\text { Loans for non-financial sector / non-financial sector deposits; } \\
\text { (Loans for non-financial sector - loans for non-financial sector) / } \\
\text { loans for non-financial sector; } \\
\text { Liquid assets / short-term liabilities; } \\
\text { Time deposits in financial institutions / time deposits from } \\
\text { financial institutions. }\end{array}$ \\
\hline $\begin{array}{l}\text { Cash flow analysis } \\
\text { Financing (cash flow) gap } \\
\text { For individual time periods, } \\
\text { 1) for contract values variant, } \\
\text { 2) for real values variant, } \\
\text { 3) for various scenarios } \\
\text { variant. }\end{array}$ & $\begin{array}{l}\text { Gap in period } i=\text { value of inflows in period } i-\text { value of outflows } \\
\text { in period } i \text {; } \\
\text { Cumulative gap = sum of gaps in period from } i \text { to } n \text {; } \\
\text { Gap in period } i=\text { value of inflows in period } i \text { / value of outflows } \\
\text { in period } i .\end{array}$ \\
\hline
\end{tabular}

Source: [Meshkova et al. 2018].

Most often the implied liquidity level measures show the relationship between liquid assets and total assets [El Mehdi 2014; Ferrouchi 2014; Alper, Anbar 2011]. In addition, these parallel analyzes also takes into account the relation of liquid assets to customer deposits and short-term funding [Vodova 2013; Grant 2012; Delechat et al. 2012; Mehmet 2014; Maechler et al. 2007; Aspachs et al. 2005; Roman, Sargu 2015]. A popular measure of liquidity risk is also a relationship 
expressing the share of loans in total assets [Roman, Sargu 2015; Athanasoglu et al. 2006; Vodovà 2011; Abreu and Mendes 2002; Rachdi 2013]. It should be also noted that the ratio that is widely used in conducted studies and reflects the relation between the value of loans granted and the level of deposits accepted. It enables the estimation of funding risk by indicating the values of stable funding sources, which are considered to be deposits mainly from the non-financial sector [Bonfim, Kim 2017; Vodovà 2011; Petria et al. 2015]. Thr determinants of individually adopted various liquidity measures do not demonstrate the same directions of dependences and the strength of effect [Wójcik-Mazur, Szajt 2015]. They are also dependent on the specifics of individual banking systems.

In the cash flow approach, an essential element of liquidity risk estimation is liquidity gap calculation. The liquidity gap for individual institutions should be based on estimating the cash flows reflecting actual inflows and outflows of funds identifying both balance sheet and off-balance items in specific, well-defined periods of time. Many authors emphasize that estimating both the inflows and outflows of funds should also take into account the process of making the numbers more real, which should be enhanced by a dynamic approach taking into account the future unanticipated changes in cash flows [Matz, Neu 2007; Bessis 2009; Schmaltz 2009; Stopczyński 2016]. Thus, it seems that this approach is similar to the presented hybrid approach, as consists in the elements of cash flow and liquid assets approach. In this approach, future cash flows should take into account the stochastic calculation of cash flows (including those with an undefined time profile), which may significantly change the liquidity position of the bank.

Nevertheless, statistical studies, in particular comparative analyses should be emphasized with the attempts to use balance sheet measures that in such an approach are about to reflect the "idea" of a liquidity gap. Few studies undertake the attempts to calculate liquidity risk as a liquidity gap that, however, is the result of relations between balance sheet elements [Chen et al. 2010; Wójcik-Mazur 2012]. In the classical approach, balance sheet measures or liquidity gap estimation can be used, that may relate both to individual financial institutions and to the banking systems of individual countries.

\section{Statistical analysis of the level of financial liquidity of commercial and cooperative banks}

The basis for the exploration undertaken in the field of assessing the impact of the determinants of liquidity risk is therefore the selection of the measures which enable evaluation. This paper analyzes the level of dependences between the liquidity risk and a group of three internal determinants in a group of commercial banks and cooperative banks in 2009-2016. The sources of information are financial data published on a monthly basis by the Financial Supervision Authority 
(KNF in Polish) for the commercial sector and cooperative banks operating in Poland. Based on the literature studies, three classical formulas were selected as liquidity measures: loans to deposits ratio, liquid assets to total assets ratio and loans to total assets ratio. These ratios as proxies for liquidity risk have been considered by many authors: Vodovà [2011], Bonfim and Kim [2017], Sufian [2011], Kosmidou et al. [2006], Sheefeni [2015] and Roman and Sargu [2015].

When choosing measures of liquidity, the level of correlation among the three proposed measures was assessed. Tables 2 to 3 show the level of correlation coefficient between the measures of liquidity risk for the group of commercial and cooperative banks respectively.

Table 2. Pearson's correlation coefficient for the liquidity measures for commercial banks with the level of significance alpha $=0,05$

\begin{tabular}{|l|c|c|c|}
\hline & Loans/deposits & $\begin{array}{c}\text { Liquid assets/ } \\
\text { total assets }\end{array}$ & $\begin{array}{c}\text { Loans/ } \\
\text { total assets }\end{array}$ \\
\hline Loans/deposits & 1 & $-\mathbf{0 . 6 6 2 3 5 8 0} *$ & $\mathbf{0 . 5 6 4 6 9 7 0 *}$ \\
\hline Liquid assets/total assets & & 1 & $-\mathbf{0 . 7 7 4 4 1 4 *}$ \\
\hline Loans/total assets & & & 1 \\
\hline
\end{tabular}

Source: own elaboration on the basis of KNF data

Table 3. Pearson's correlation coefficient for the liquidity measures for cooperative banks at significance level alfa $=0.05$

\begin{tabular}{|l|c|c|c|}
\hline & Loans/deposits & $\begin{array}{c}\text { Liquid assets/ } \\
\text { total assets }\end{array}$ & $\begin{array}{c}\text { Loans/ } \\
\text { total assets }\end{array}$ \\
\hline Loans/deposits & 1 & $-\mathbf{0 . 5 5 6 9 5 1}$ & $\mathbf{0 . 6 3 9 3 6 4 2}$ \\
\hline Liquid assets/total assets & & 1 & $\mathbf{- 0 . 9 0 7 9 4}$ \\
\hline Loans/total assets & & & 1 \\
\hline
\end{tabular}

Source: own elaboration on the basis of KNF data.

The data presented in Tables 2 to 3 show that the lowest level of correlation was characteristic for loans/deposits and loans/total assets measures for particular types of banks. It was therefore concluded that the measure of credits/deposits is the optimal indicator of liquidity risk for specific financial data.

Analyzing the level of liquidity of banks operating in Poland, the terminology defined in the financial reporting presented by the Financial Supervision Authority was adopted. In this perspective therefore, the level of liquidity for the commercial banking sector and cooperative banks was estimated. The number of banks constituting these two sectors and their shares in the total assets of the Polish banking sector are shown in Table 4 . 
Table 4. Number of banks and their shares in total assets of the Polish banking sector in 2013-2017

\begin{tabular}{|l|c|c|c|c|c|}
\hline & 2013 & 2014 & 2015 & 2016 & 2017 \\
\hline \multicolumn{7}{|c|}{ Number of banks } \\
\hline Commercial banks & 67 & 64 & 63 & 61 & 61 \\
\hline Affiliating banks & 2 & 2 & 2 & 2 & 2 \\
\hline Cooperative banks & 571 & 565 & 560 & 558 & 558 \\
\hline \multicolumn{7}{|c|}{ Share in total assets of Polish banking sector (\%) } \\
\hline Commercial banks & 90.8 & 91.1 & 91.2 & 90.7 & 90.2 \\
\hline Affiliating banks & 2.3 & 2.0 & 2.0 & 2.2 & 2.4 \\
\hline Cooperative banks & 6.9 & 6.9 & 6.8 & 7.1 & 7.4 \\
\hline
\end{tabular}

Source: own elaboration.

It should be emphasized that the analyzed commercial banking sector represents a dominant share in the total assets of the Polish banking system. Cooperative banking is an important element of the Polish financial system, despite its relatively low share in the banking sector assets, amounting to almost $10 \%$ in 2017 (include affiliating banks). Cooperative banks play a significant role in local communities, provided a high share in the financing of agriculture as well as a notable level of engagement in financing small and medium-sized enterprises and LGUs. In the Polish banking system, cooperative banks (with the exception of two) are affiliated in affiliating banks, which operate as joint-stock companies (BPS SA in Warsaw and SGB-Bank SA in Poznań). It should be emphasized that in 2015, Institutional Protection Schemes (IPS) were established in Polish cooperative banks affiliations with the purpose of ensuring the liquidity and solvency of each participant under the rules set out in the Act and in the protection scheme agreement. At the end of 2017 two existing institutional protection schemes (IPS BPS and IPS SGB) covered nearly $90 \%$ of the cooperative banks. Due to the local character and limited capabilities of extending the lending activity of cooperative banks, their specificity is an asset structure slightly different from commercial banks. This relates to the higher share of liquid assets in total assets, usually deposited in affiliating banks. Figure 1 presents the relation of non-financial sector loans to deposits from this sector, including institutional protection schemes (IPS BPS and IPS SGB). The data presented in Figure 1 indicate that cooperative banks still dispose of high reserves in terms of the ability to launch lending action, because the value of deposits acquired from the non-financial sector significantly exceeds the level of credit activity of both IPSs mentioned above, as well as of banks outside the IPS. As a result the whole cooperative banking sector is characterized by high levels of liquid assets and a negative financing gap. For this reason it was acknowledged that the factors affecting liquidity risk may have different effects in cooperative and commercial bank groups. 


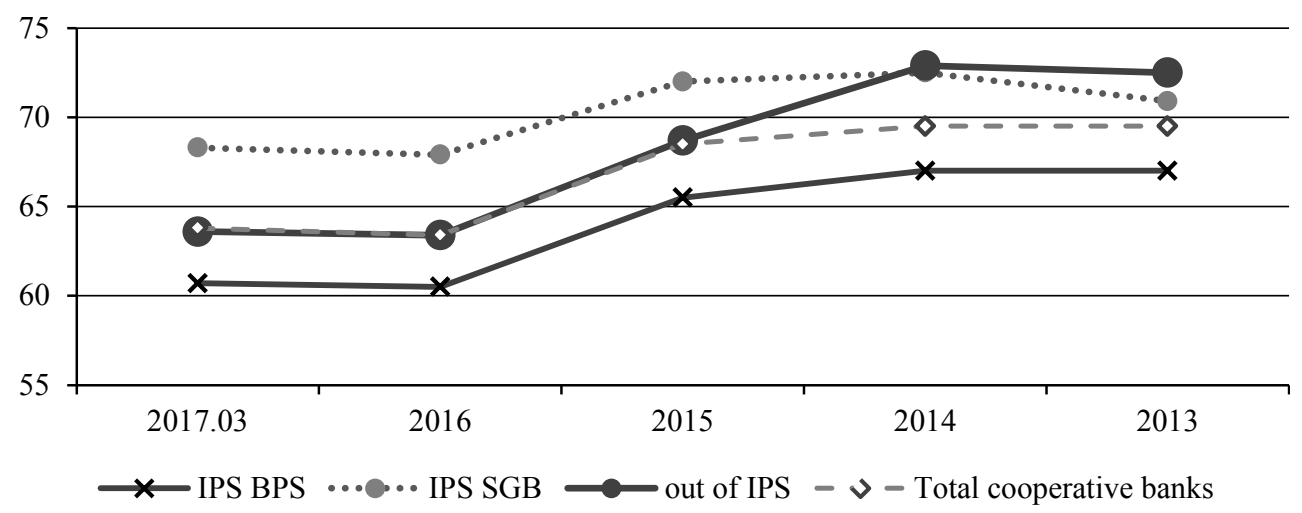

Fig. 1. Relation of non-financial sector loans to non-financial sector deposits including IPS in the Polish cooperative bank sector in 2013-2017

Source: own elaboration.

\section{Analysis of the correlation level of liquidity risk and internal determinants}

On the basis of literature studies and research already carried out [Wójcik-Mazur 2012; Wójcik-Mazur, Szajt 2015], the liquidity risk determinants include as was already mentioned, credit risk, performance measures and the level of capital ratio. The value of the indicated ratios were estimated based on monthly data presented by the KNF for the whole group of cooperative and commercial banks. The methodologies for the calculation of the indicators are presented in Table 5.

Table 5. Internal determinants of liquidity risk

\begin{tabular}{|c|c|c|}
\hline Measure & Structure & Source of data \\
\hline ROE & Net profit/equity & Polish Financial Supervision Authority KNF \\
\hline Credit risk & $\begin{array}{l}\text { Value of past due } \\
\text { loans/gross loans }\end{array}$ & Polish Financial Supervision Authority KNF \\
\hline Capital ratio & Equity/total assets & Polish Financial Supervision Authority KNF \\
\hline
\end{tabular}

Source: own elaboration.

In the existing empirical literature we can find a broad area of research which reflects the relationship between profitability in banking activity and the group of internal determinants including liquidity risk. These studies focused on commercial banks according to different criteria based on cross-country evidence, country specific, size of banks etc. Many authors [Abreu, Mendes 2002; Kosmidou et al. 2005; Garcia-Herrero et al. 2009; Guru et al. 2002; Graham, Bordelean 2010; 
Al-Harbi 2017] find evidence on the relationships between liquidity and profitability. Referring to the impact of bank liquidity is negatively related to the profitability of commercial banks. However, Kosmidou et al. [2005], recognize the existence of a significant positive relationship between these determinants.

We examine the correlation between the liquidity of banks and three internal determinants. Table 6 presents the results of the linear dependences between funding risk and the indicated group of measures.

The Pearson's correlation analysis showed that all the tested statistical relationships are significant, which indicates the existence of linear relationships both between the rate of return (ROE), and the level of credit risk and between capital ratio and the level of liquidity.

Table 6. Pearson's correlation coefficient for the liquidity measures of commercial and cooperative banks

\begin{tabular}{|l|c|c|c|}
\hline & ROE & Credit risk & Capital ratio \\
\hline $\begin{array}{l}\text { loans/deposits } \\
\text { commercial banks) }\end{array}$ & $\mathbf{0 . 2 5 2 3 6 6 *}$ & $\mathbf{- 0 . 6 8 1 6 2 4 *}$ & $\mathbf{- 0 . 5 4 6 7 9 2 *}^{*}$ \\
\hline $\begin{array}{l}\text { loans/deposits } \\
\text { (cooperative banks) }\end{array}$ & $\mathbf{0 . 5 2 8 5 3 5 *}$ & $\mathbf{- 0 . 8 1 7 6 1 5 *}$ & $\mathbf{0 . 8 4 7 6 5 8 *}$ \\
\hline
\end{tabular}

*Statisticaly significant values (alpha $=0.01)$.

Source: own elaboration.

The study shows that both the level of operating profitability and credit risk are dependent on the value of liquidity maintained both for the group of commercial and cooperative banks. By evaluating the relationship between liquidity risk and operational efficiency, a much stronger positive correlation is visible in the cooperative banking sector. Therefore it seems that it is caused by the fact of maintaining liquidity reserves, which in the event of starting lending activity significantly increases interest revenues while not generating excessive additional increase of interest cost (hypothesis 1). Cooperative banks in the financing the growing lending activities are not compelled to acquire additional, more expensive sources of funding from the financial markets, because they have accumulated reserves in the form of deposits from the non-financial sector. In the group of commercial banks a decrease in liquidity reserve increases profitability ratios, however this relationship is much weaker. As in the previous case, loan growth forces the acquisition of additional sources of financing at a cost higher than the local wholesale market, and because of that the relationship is positive but much weaker.

The general overview of the empirical literature shows a positive relationship between liquidity and credit risk. This is addressed in the publications such as, Acharya and Viswanathan [2011], Gorton and Metrick [2012] and He, Xiong 
[2012], yet Imbierowicz and Rauch [2014] find evidence that there is no reliable relationship between liquidity risk and credit risk in banks. In this article, while evaluating the relation between financial liquidity level and credit risk, it should be noted that there is a strong negative correlation both in commercial and cooperative banks groups (hypothesis 2). This probably results from the specific character of liquidity risk, confirming its anticyclical nature [Wójcik-Mazur 2012]. As emphasized in the current research, significant increase in lending activity is realized by the banking sector in the event of the economic growth. Under such circumstances the credit risk level is low and the potential growth of newly-started loans makes the ratio of past due loans to total receivables decrease. This negative correlation is much stronger in the case of cooperative banks which are more responsive to the economic situation and, as it seems, implement a much more restrictive lending policy.

The measure demonstrating the relation between liquidity risk and capital ratio that reflects the ratio of equity share in total assets is observed for a strong correlation, however its direction is different in the discussed groups of banks (hypothesis 3 ). In the commercial banks sector the funding risk level is negatively correlated with the value of that ratio. This means that the increase in liquidity risk is accompanied by the decrease in the share of equity in total assets. The growth in lending activity results in the balance sheet total increase, but it is not accompanied by the proportional progress in equity. this may be caused by the fact that commercial banks are more focused on increasing profitability than on enhancing financial safety. The opposite situation takes place in the cooperative banks sector. These results are not consistent with those expected (hypothesis 3 negatively verified). It should be noted that cooperative banks hold a much higher liquidity buffer in comparison to commercial banks. They invest their free funds in associating banks and in debt instruments. Therefore, it seems that the surplus funds held may form a source of newly-started loans, which does not have to be accompanied by a strong increase in deposits obtained from the non-financial sector. The positive correlation between funding risk and the share of equity in total assets suggests that banks, when increasing lending activity (still financed from liquidity surpluses), implement a conservative policy, simultaneously increasing the value of equity. However, the policy aimed at the increase of the equity share may not only originate from the desire to enhance financial safety but also attempt to increase the lending potential, especially in the area of business activity financing by acquiring new customers that require more advanced products and in particular higher loans. As it may seem, external limits in relation to equity value in the lending activity of cooperative banks in particular, limit the possibilities of lending to the non-financial sector. Increasing the equity is of key importance for the possibility of financing new ventures and acquiring new customers with higher credit needs, especially given the existing high liquidity buffer in the sector of cooperative banks. 


\section{Conclusions}

The conducted study of correlation between a measure of liquidity and a group of internal determinants showed the existing relations in the sector of commercial and cooperative banks. It should be emphasized that on the basis of the financial data presented for the cooperative and commercial banking sector, a correlation between liquidity risk and efficiency measures, and between credit risk and the level of capital ratio has been shown. The direction of the diagnosed relations was the same for both performance indicators and credit risk, however stronger relations occurred in the group of cooperative banks. A different direction of correlation in terms of the measure expressing the relationship of equity in total assets to liquidity risk was a characteristic of the cooperative banks. The estimated Pearson's correlation showed that the cooperative banks, by reducing their liquidity reserves, increase in parallel the value of their equity, which means that in periods of good economic conditions, financial security is a high priority for them. Nevertheless, it seems that the main element of this policy is the increase in lending capability as well as in the potential requirements in terms of supervisory regulations. The activities related to the increase of own funds result from incentives of banking supervision because they enable, on the one hand, the development of lending activity and on the other, the fulfilment of higher capital requirements according to the CRDIV/CRR European regulation package (including MREL).

\section{Bibliography}

Abreu M., Mendes V., 2002, Commercial bank interest margins and profitability: Evidence from EU countries, University of Porto Working Paper, no. 245.

Acharya V., Viswanathan S., 2011, Leverage, moral hazard and liquidity, Journal of Finance 66, pp. 99-138.

Al-Harbi A., 2017, Determinants of banks liquidity: evidence from OIC countries, Journal of Economic and Administrative Sciences, vol. 33(2), pp. 164-177.

Alper D., Anbar A., 2011, Bank specific and macroeconomic determinants of commercial bank profitability: Empirical evidence from Turkey, Business and Economics Research Journal, vol. 2, no. 2, pp. 139-152.

Aspachs O., Nier E., Tiesset M., 2005, Liquidity, Banking Regulation and the Macroeconomy. Evidence on Bank Liquidity Holdings from a Panel of UK-resident Banks, Bank of England Working Paper.

Athanasoglu P., Delis M., Staikouras C., 2006, Determinants of Bank Profitability in the South Eastern European Region, Munich Personal RePEc Archive, no. 10274.

Basel III, 2013, The Liquidity Coverage Ratio and liquidity risk monitoring tools, The Basel Committee on Banking Supervision, Bank for International Settlements, January.

Basel III, 2014, The Net Stable Funding Rato, The Basel Committee on Banking Supervision. Bank for International Settlements, October.

Bessis J., 2009, Risk Management in Banking, John Wiley \& Sons Inc., Chichester. 
Bonfim D., Kim M., 2017, Liquidity risk and collective moral hazard. European Banking Center discussion paper no. 2012-024,. SSRN: https://ssrncom/abstract=2163547 or http://dx doi org/ 102139/ssrn2163547, Accessed 1 Feb. 2017.

Brunnermeier M., Pedersen L., 2009, Market liquidity and funding liquidity, Review of Financial Studies, 22(6), pp. 2201-2238.

Chen C., Kao Y., Yeh L., 2010, Bank liquidity risk and performance, International Monetary Fund, Working Paper.

Deléchat C., Henao C., Muthoora P., Vtyurina S., 2012, The Determinants of Banks' Liquidity Buffers in Central America, IMF Working Paper, December.

Dziwok E., 2015, Metody pomiaru ryzyka płynności w banku, Studia Ekonomiczne, Zeszyty Naukowe Uniwersytetu Ekonomicznego w Katowicach, nr 238, pp. 7-15.

El Mehdi, Ferrouhi E., 2014, Bank liquidity and financial performance: Evidence from the Moroccan banking industry, Business: Theory and Practice, p. 351-361.

Garcia-Herrero A., Gavila S., Santabarbara D., 2009, What explains the low profitability of Chinese banks, Banco de Espana Working Paper, June 2, no. 0910.

Gorton G., Metrick A., 2012, Securitization, NBER Working Paper no. 18611.

Graham C., Bordelean E., 2010, The impact of liquidity on bank profitability, Working Paper (2010 38), Bank of Canada, December.

Grant J., 2012, Liquidity buffers of Australian-owned ADI, The Finsia Journal of Applied Finance, issue 3.

Guru B., Staunton J., Balashanmugam B., 2002, Determinants of commercial bank profitability in Malaysia, Paper presented at the 12th Annual Australian Finance and Banking Conference, 16-17 December, Sydney.

He Z., Xiong W., 2012, Rollover risk and credit risk, Journal of Finance, LXVII, (2), pp. 391-430.

Imbierowicz B., Rauch C., 2014, The relationship between liquidity risk and credit risk in banks, Journal of Banking \& Finance, vol. 40, pp. 242-256.

Jajuga K., 2009, Pomiar stabilności i zarzadzania ryzykiem systemu bankowego - lekcje z kryzysu, [in:] Globalny kryzys finansowy i jego konsekwencje w opiniach ekonomistów polskich, ZBP, Warszawa, pp. 25-30.

Kosmidou K., Pasiouras F., Doumpos M., Zopounidis C., 2006, Assessing performance factors in the UK banking sector: A multicriteria approach, Central European Journal of Operations Research, February, vol. 14, issue 1, pp. 25-44.

Kosmidou K., Tanna S., Pasiouras F., 2005, Determinants of profitability of domestic UK commercial banks: Panel evidence from the period 1995-2002, Money Macro and Finance (MMF) Research Group Conference 2005.

Maechler A.M., Mitra S., Worrell D., 2007, Decomposing Financial Risks and Vulnerabilities in Eastern Europe, IMF Working Paper 248.

Marcinkowska M., Wdowiński P., Flejterski S., Bukowski S., Zygierewicz M., 2014, Wpływ regulacji sektora bankowego na wzrost gospodarczy - wnioski dla Polski, NBP Materiały i Studia, Instytut Ekonomiczny, Warszawa, nr 305.

Matz L., Neu P., 2007, Liquidity Risk. Measurement and Management, Wiley.

Mehmet G., 2014, An empirical study on liquidity risk and its determinants in Bosnia and Herzegovina, The Romanian Economic Journal, June.

Meshkova E., Wawrzyniak D., Wójcik-Mazur A., 2018, Risk management in banking. Credit, market and technology perspective, PTE Section, Częstochowa.

Niedziółka P., 2014, Skorygowany o ryzyko kredytowe pomiar płynności banku jako narzędzie wsparcia procesu zarządzania stabilnościa finansowa, Problemy Zarządzania, vol. 12, nr 4, (48), pp. 132-150. 
Nikolaou K., 2009, Liquidity (risk) concepts: Definitions and interactions, ECB Working Paper 1008.

Petria N., Capraru B., Ihnatov I., 2015, Determinants of banks' profitability: Evidence from EU 27 banking systems, 7th International conference on globalization and higher education in economics and business administration: GEBA, Procedia Economics and Finance.

Principles for Sound Liquidity Risk Management and Supervision, 2008, The Basel Committee on Banking Supervision, Bank for International Settlements, September, Press \& Communications CH-4002 Basel, Switzerland.

Rachdi H., 2013, What determines the profitability of banks during and before the international financial crisis? Evidence from Tunisia, International Journal of Economics, Finance and Management, 2(4), pp. 330-337.

Roman A., Sargu A., 2015, The impact of bank-specific factors on the commercial banks liquidity: Empirical evidence from CEE countries, Proc Econ Finance, 20, pp. 571-579.

Schmaltz C., 2009, A Quantitative Liquidity Model for Banks, Gabler.

Sheefeni J., 2015, Evaluating the impact of bank specific determinants of non-performing loans in Namibia, Journal of Emerging Issues in Economics, Finance and Banking, 4(2), pp. 1525-1541.

Stopczyński A., 2016, Zarządzanie ryzykiem płynności w banku, [in:] K. Jajuga, T. Czerwińska (eds.), Ryzyko instytucji finansowych, CH Beck, Warszawa, pp. 409-432.

Sufian F., 2011, Profitability of the Korean banking sector: Panel evidence on bank-specific and macroeconomic determinants, Journal of Economics and Management 7(1), pp. 43-72.

Vento G., La Ganga P., 2009, Bank liquidity risk management and supervision: What lessons from recent market turmoil?, Journal of Money, Investment and Banking, no 10.

Vodovà P., 2011, Liquidity of Czech commercial banks and its determinants, International Journal of Mathematical Models and Methods in Applied Sciences, 6(5), pp. 1060-1067.

Vodovà P., 2013, Determinants of commercial banks' liquidity in Poland, European Financial and Accounting Journal, 3, pp. 24-37.

Wójcik-Mazur A., 2012, Zarządzanie ryzykiem płynności w bankach, Politechnika Częstochowska, Częstochowa.

Wójcik-Mazur A., Szajt M., 2015, Determinants of liquidity risk in commercial banks in the European Union, Argumenta Oeconomica, 2(35), pp. 25-47.

Zaleska M., 2016, Ryzyko bankowe - zmiany w sektorze bankowym Unii Europejskiej; [in:] K. Jajuga, T. Czerwińska (eds.), Ryzyko Instytucji finansowych, C.H. Beck, Warszawa. 